\title{
Kinetic Study of Immobilized Whole-Cell Lipase Rhizopus Oryzae as Biocatalyst in Biodiesel Synthesis through Non-Alcohol Route
}

\author{
H. Hermansyah, M. B. Faiz, and R. Arbianti
}

\begin{abstract}
Utilizing whole-cell biocatalyst is a potential way to reduce catalyst cost in biodiesel production using lipase as catalyst. Whole-cell of Rhizopus oryzae was cultivated by one-step and two-step method and was immobilized on Biomass Support Particles (BSPs) and chitosan-TPP bead. Immobilized whole-cells on BSPs produce $11 \%$ (one-step) and $12 \%$ (two-step) FAME yield. While, FAME yield produced by immobilized whole-cell in chitosan-TPP beads are $23 \%$ (one-step) and $22 \%$ (two-step). Kinetic model based Michaelis-Menten used was found to fit fairly the substrate and product concentration profile. Value of $K_{m}$ and $V_{\max }$ for $R$. oryzae whole-cell immobilized on BSP are 4 mole $L^{-1}, 0.05$ mole $L^{-1} h^{-1}$ (one-step) and 3 mole $L^{-1}, 0.04 \mathrm{~mol} \mathrm{~L}^{-1} h^{-1}$ (two-step). While, for immobilized whole-cell in chitosan-TPP bead, the values are 0.3 mole $L^{-1}, 0.01$ mole $L-1 h^{-1}$ and 0.2 mole $L^{-1}, 0.008$ mole L-1h-1 for single-step and two-step respectively.
\end{abstract}

Index Terms-Biodiesel, immobilization, Michaelis-Menten, whole-cell.

\section{NOMENCLATURE}

F-1 Suspended whole-cell $R$. oryzae cultivated by single-step cultivation method

F-2 Suspended whole-cell $R$. oryzae cultivated by two-step cultivation method

IB-1 Immobilized whole-cell $R$. oryzae on BSPs cultivated by single-step cultivation method

IB-2 Immobilized whole-cell $R$. oryzae on BSPs cultivated by two-step cultivation method

IK-1 Immobilized whole-cell $R$. oryzae in chitosan-TPP beads cultivated by single-step cultivation method

IK-2 Immobilized whole-cell $R$. oryzae in chitosan-TPP beads cultivated by two-step cultivation method

KZ Immobilized commercially $C$. rugosa lipase on zeolite

KK Immobilized commercially C. rugosa lipase in chitosan-TPP beads

[P] FAME consentration (mole $\left.\mathrm{L}^{-1}\right)$

[S] Triglyceride concentration $\left(\right.$ mole $\left.\mathrm{L}^{-1}\right)$

$t \quad$ Time (h)

$V_{\max } \quad$ Maximum interesterification rate $\left(\right.$ mole $\mathrm{L}^{-1}$ $\mathrm{h}^{-1}$ )

$K_{m} \quad$ Michaelis constant $\left(\right.$ mole $\left.\mathrm{L}^{-1}\right)$

\section{INTRODUCTION}

In the past decade, biodiesel has attracted considerable attention as a renewable, biodegradable and non-toxic fuel [1]. Current technology for biodiesel production, using an alkali or an acid catalyst, has several important limitations such as requires feedstock free of water, produce salts, generate glycerin as a low- grade by-product, etc [2]. In the other side, utilizing lipase as catalyst for biodiesel production over several advantage, such as require lower heating, works even in the presence of water, produces no salts [2]. Lipases have up to 74 times higher productivity than alkali catalyst [3].

Lipase is easy to be deactivated by alcohol, which is a reactant in biodiesel synthesis reaction. Therefore, we have developed new method to maintain the activity and stability of the biocatalyst during reaction by using methyl acetate as an acyl donor [4]. Unfortunately, the price of lipase is expensive due to purification procedures [2]. Haas et al. reported that catalyst cost in biodiesel production by using enzyme is $0.14 \mathrm{US} \$$ per $\mathrm{kg}$ per $\mathrm{kg}$ ester [5]. It is much higher than by using $\mathrm{NaOH}$ which is 0.006 US\$ per kg ester [5].

In order to lower the catalyst cost, we used enzyme immobilization method in various support to make the lipase become reusable due to its easy recovery from the reaction mixture [6]-[9]. We have also developed kinetic model based on Michaelis-Menten and Ping Pong Bi Bi Mechanism describing the interesterification behavior of the triglyceride with methyl acetate to produce biodiesel using lipase [4], [6].

Although immobilization makes enzyme become reusable, but the process is time and cost consuming [6], [7]. Utilizing whole-cell overproducing intracellular lipase, such as Rhizopus oryzae, as biocatalyst in biodiesel synthesis is a potential way to reduce the biocatalyst cost [10]. The preparation of a biocatalyst requires no complex purification process, and the prepared whole-cells could be directly used as lipase containers [11].

Cells immobilization enables the whole-cell biocatalyst to be reused in subsequent reactions [2]. Whole-cells are frequently entrapped in biomass support particles (BSPs) [1], [10]-[15]. In this research, we also immobilized whole-cells of $R$. oryzae on BSP. Besides, the cells were immobilized by different method, i.e. encapsulation, in chitosan-TPP beads. $R$. oryzae was cultivated by different method, i.e. single-step and two-step cultivation.

Works which deal with modeling of enzymatic interesterification for whole-cell catalyzed biodiesel production are not often found in the literature. This work also presents a study of kinetics of enzymatic reaction of
Manuscript received May 7, 2014; revised July 17, 2014.
H. Hermansyah, M. B. Faiz, and R. Arbianti are with Universitas Indonesia, Depok 16424, Indonesia (e-mail: heri@che.ui.ac.id, merisa.faiz@ui.ac.id, arbianti@che.ui.ac.id). 
cooking oil and methyl acetate for biodiesel production using immobilized $R$. oryzae whole-cell as biocatalyst. The kinetic was based on Michaelis-Menten mechanism.

\section{MATERIALS AND MeTHODS}

\section{A. Materials}

All experiments were carried out using $R$. oryzae obtained from School of Life Science and Technology, Bandung Institute of Technology, Indonesia. Potato Dextrose Broth (PDB) was obtained from BD DifcoTM (USA). Trypton, $\mathrm{NaNO}_{3}, \mathrm{KH}_{2} \mathrm{PO}_{4}, \mathrm{MgSO}_{4} .7 \mathrm{H}_{2} \mathrm{O}$, glutaraldehyde and methyl acetate were purchased from Merck (Darmstadt, Germany). Olive oil, cooking oil, BSPs, chitosan, acetic acid and tripolyphosphate (TPP) were obtained locally.

\section{B. Suspended Whole-Cell Preparation}

There are two different methods used for fungi cultivation, i.e. single-step and two-step method. One-step cultivation was carried out using $50 \mathrm{ml}$ of PDB medium at room temperature $\left(25^{\circ} \mathrm{C}\right)$ for 24 hours on reciprocal shaker at 60 oscillations. Two-step method was worked following method of Jin and Bierma [2]. The method consisted of pre-incubation and incubation step. For pre-incubation, Erlenmeyer flask $(100 \mathrm{ml})$ containing $50 \mathrm{ml}$ of PDB were inoculated by aseptically transferring spores from a potato dextrose agar plate. For the incubation step, the filamentous fungi were aseptically transferred to other Erlenmeyer flask $(100 \mathrm{ml})$ containing $50 \mathrm{ml}$ of basal medium. The basal medium contained, in $1 \mathrm{~L}$ of distilled water: $70 \mathrm{~g}$ trypton, $1 \mathrm{~g}$ $\mathrm{NaNO}_{3}, 1 \mathrm{~g} \mathrm{KH}_{2} \mathrm{PO}_{4}, 0.5 \mathrm{~g} \mathrm{MgSO} 4.7 \mathrm{H}_{2} \mathrm{O}$ and $30 \mathrm{~g}$ olive oil. Each step in two-step method was conducted using the same operating condition as in single-step cultivation method.

\section{Whole-Cell Immobilization on BSPs}

Immobilization was carried out following method of Ban, et al. [12]. R. oryzae cells were immobilized on Biomass Support Particles (BSPs). The BSPs used for immobilization were $6 \mathrm{~mm}$ cubes of polyurethane foam. Immobilization was effected by placing $1 \mathrm{~g}$ BSPs inside a flask together with the medium. The cells became well immobilized within the BSPs as a natural consequence of their growth during shake-flask cultivation [12]. The immobilized whole-cell was separated from the culture broth by filtration. After washing with tap water for $1 \mathrm{~min}$, they were treated with $0.1 \%$ glutaraldehyde solution for 1 hour.

\section{Whole-Cell Immobilization in Chitosan-TPP Beads}

Whole-cell encapsulation in chitosan-TPP bead was carried out after pre-incubation. Encapsulation process was started by mixing $R$. oryzae cells into chitosan $(0.5 \mathrm{~g})$ dissolved in acetic acid 3\%v/v (9ml). The mixture then was dripped into TPP solution $2 \% \mathrm{w} / \mathrm{v}$. This process would support bead forming of chitosan-TPP. Such process was conducted for 4 hours.

\section{E. Biodiesel Synthesis through Non-Alcohol Route}

The interesterification reaction was carried out at $37^{\circ} \mathrm{C}$ in $250 \mathrm{ml}$ screw-cap bottle with incubation on a reciprocal shaker 150rpm). Cooking oil and methyl acetate were used with 1:12 mole ratio. The whole-cell biocatalyst added was $10 \%$ of total reactant mass."

\section{F. Analysis}

Reactant and product were analyzed using a HPLC system (L-7100, Hitachi, Ltd., Tokyo, Japan) equipped with an Inertsil ODS column (particle size $5.0 \times 10^{-4} \mathrm{~cm}$, i.d. $0.46 \mathrm{~cm}$, length $25 \mathrm{~cm}$, GL Science, Inc., Tokyo, Japan) and a UV detector (L-7400, Hitachi,Ltd., Tokyo, Japan) at $210 \mathrm{~nm}$. Temperature of the column oven was $313 \mathrm{~K}$. The mobile phase composition was methanol: acetone $=100: 0(\mathrm{v} / \mathrm{v})$ for $20 \mathrm{~min}$ and then the acetone ratio increased up to $20 \%(\mathrm{v} / \mathrm{v})$ and the value was maintained from $21 \mathrm{~min}$ to $35 \mathrm{~min}$. The flow rate of the mobile phase was $1.0 \mathrm{~cm}^{3} \mathrm{~min}-1$.

\section{G. Kinetic Modelling}

Michaelis-Menten kinetic (Eq. 1 and Eq. 2) based model was used to predict substrate and product concentration along reaction time.

$$
\begin{gathered}
\frac{d[P]}{d t}=\frac{V_{\max }[S]}{K_{m}+[S]} \\
\frac{d[S]}{d t}=\frac{V_{\max }[S]}{K_{m}+[S]}
\end{gathered}
$$

\section{RESULTS AND DISCUSSIONS}

\section{A. Catalytic Performance}

1) Suspended whole-cell

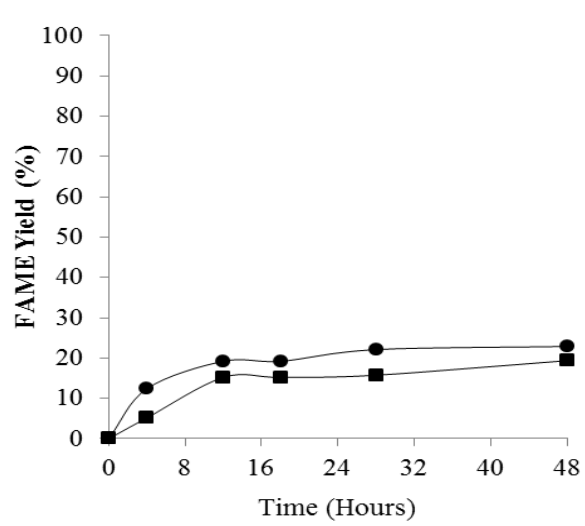

Fig. 1. Time course of FAME yield obtained with suspended whole-cell. F-1 $\square$ F-2.

To investigate the effect of cultivation method to catalytic performance of suspended whole-cell, we tried to use two different cultivation methods for fungi propagation. Fig. 1 shows the time course of FAME yield produced by reaction using suspended whole-cell cultivated by single-step and two-step method. When $R$. oryzae cells were cultivated by two-step method, the reaction produced lower FAME yield (19\%) than when the cells were cultivated by single-step method (23\%). Hama et al. reported that $R$. oryzae produces two type lipase bound to cell wall and cell membrane. In suspended cells, the amount of membrane-bound lipase decreased sharply with cultivation time. Furthermore, the 
basal medium used in two-step cultivation method contained $30 \%$ olive oil which is consisted of $55-83 \%$ oleic acid. The unsaturated fatty acid existence in medium broth altered cell membrane permeability become more permeable [1] inducing lipase secretion.

\section{2) Immobilized whole-cell on BSPS}

In submerged cultures of filamentous fungi, cells form strands of interlocking hyphae. Agitation subjected to fungi and the medium growth increased oxygen transfer which allowed the fungal hyphae became entrapped inside the foam.

When the immobilized whole-cell cultivated by two-step method, the biocatalyst synthesized higher FAME yield $(12 \%)$ than by single-step (11\%). Cell morphology intensely affect enzyme productivity. Though the relationship of cell morphology and enzyme secretion depends on fungal strain and enzyme type, cell immobilization inducing pellet formation strongly inhibit $R$. oryzae lipase, particularly from the membrane. Moreover, immersed biocatalyst in glutaraldehyde solution induces intra- and inter-molecular cross-linking of lipase [11].

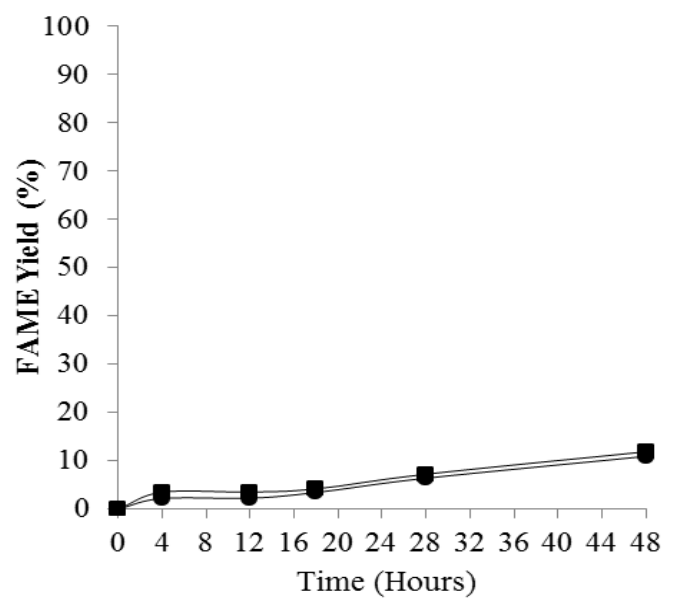

Fig. 2. Time course of FAME yield obtained with immobilized whole-cell on BSPs. IIB-1 IIB-2.

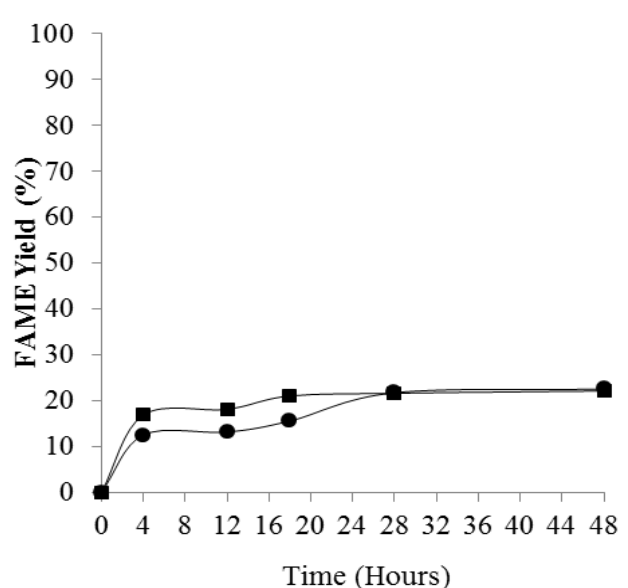

Fig. 3. Time course of FAME yield obtained with Immobilized whole-cell in Chitosan-TPP Beads. IK-1 $\mathbf{I K}-2$.

It is noteworthy that the curve shape indicates that at 48th hour the biocatalysts have not achieved the maximum yield yet (Fig. 2). It might be due to the entrapment whole-cell on BSPs increases mass transfer resistance. Thereby, there is possibility to increase the methyl ester yield by prolonging the reaction time.

\section{3) Immobilized whole-cell in Chitosan-TPP}

$R$. oryzae cells were encapsulated in chitosan-TPP beads. The beads were formed as ionic interaction between amino group of chitosan and anionic group of TPP.

Fig. 3 shows that the immobilized whole-cells cultivated by two-step methods, the FAME produced were lower than one-step. Such trend is exhibited by suspended whole-cell. It is indicated that the immobilization did not occurred intactly. Moreover, it was reported that chitosan-TPP beads have low mechanical stability.

4) Comparison with immobilized commercially lipase

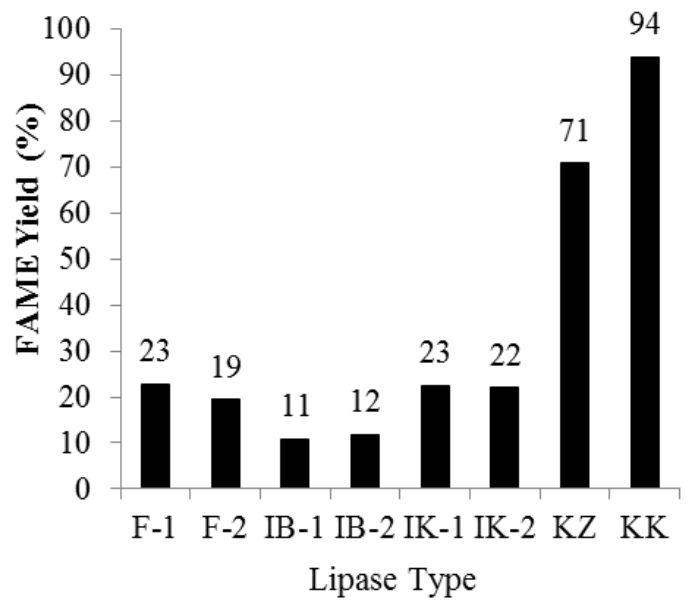

Fig. 4. FAME yield Comparison using different lipase type.

Comparisons of FAME yield obtained using whole-cell biocatalyst and immobilized commercial lipase are shown in Fig. 3. The data of immobilized commercially lipase was obtained from our previous experimental result. The reaction was carried out using $4 \%$ (w/w) biocatalyst and 50 hours reaction time. Fig. 3 shows that both immobilized commercial lipases exhibit remarkably higher FAME yield than suspended and immobilized whole-cell.

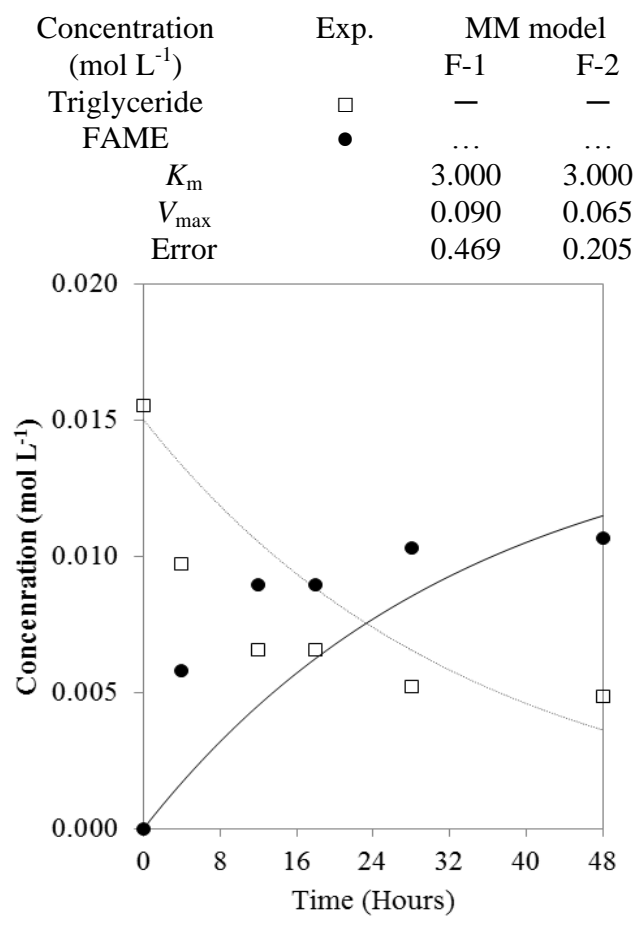




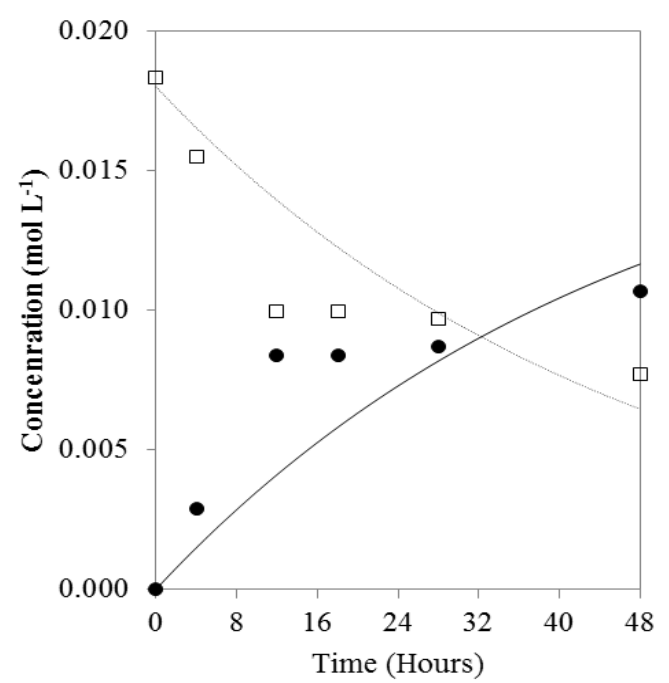

Fig. 5. Triglyceride and FAME profile using suspended whole-cell.
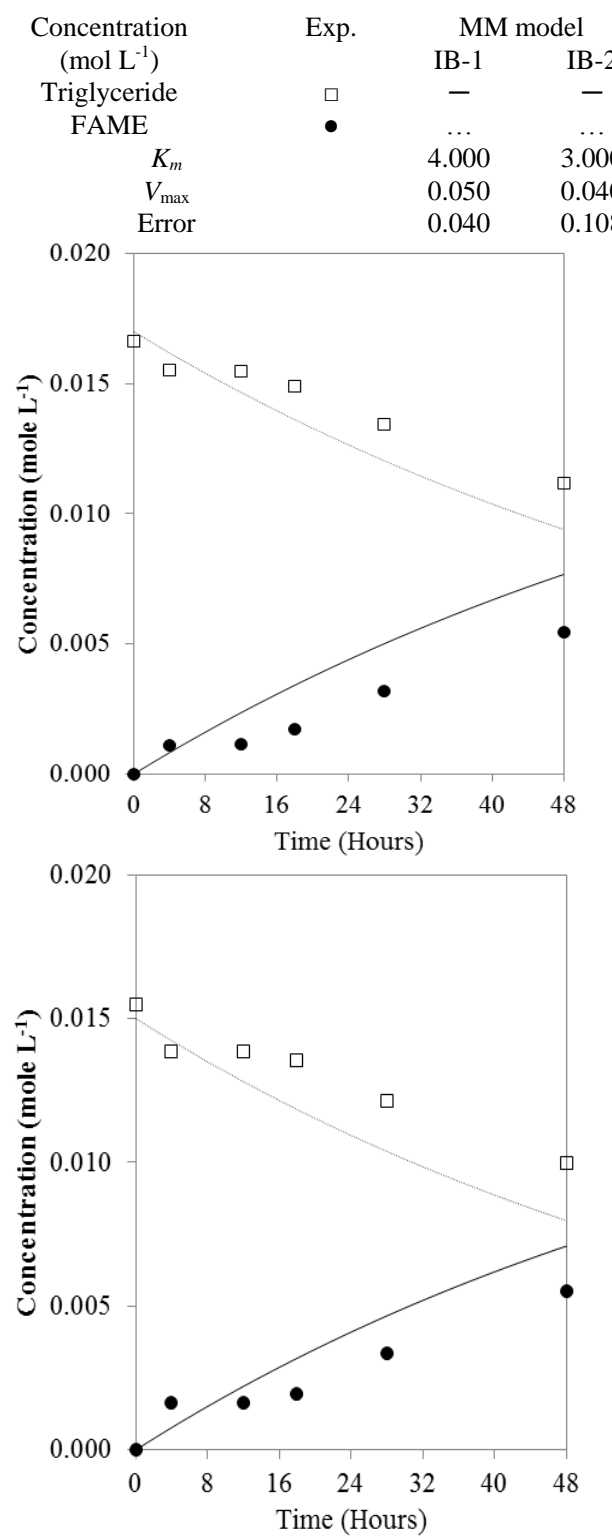

Fig. 6. Triglyceride and FAME profile using immobilized whole-cell on BSPs.

\section{B. Model Verification}

\section{1) Suspended whole-cell}

Fig. 5 shows that the model fit fairly with the experimental data. F-1 has higher $V_{\max }$ than F-2. Thus, it is predicted that F-1 could achieve higher maximum interesterification rate than F-2. However, F-1 needs more substrate than F-2 to achieve half of its maximum reaction rate. This is indicated by $K_{m}$ value.

\section{2) Immobilized whole-cell on BSPS}

Comparison of prediction and experimental data of triglyceride and methyl ester concentration is shown in Fig. 6. Both for single-step and two-step, the curve indicated that the reactions have not achieved their maximum rate yet. Therefore, we could predict that immobilized whole-cell could produce higher FAME yield by prolonging the reaction time.
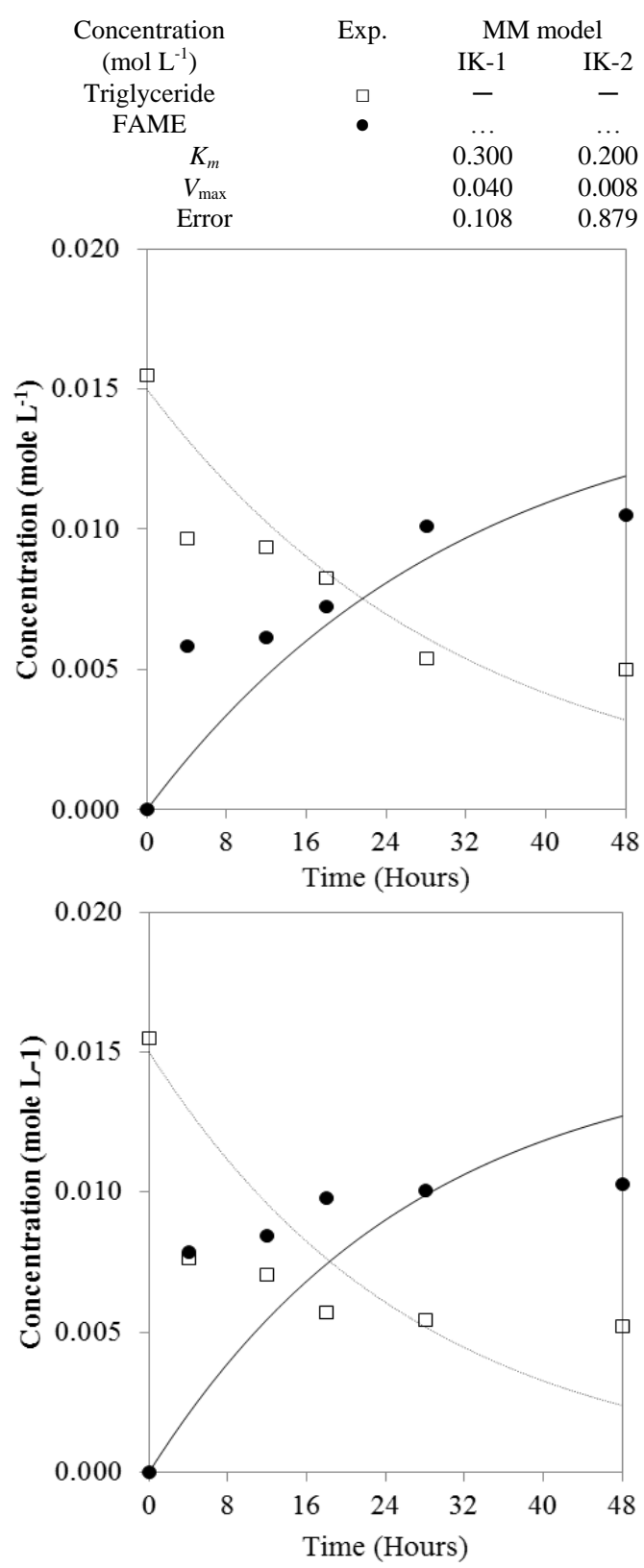

Fig. 7. Triglyceride and FAME profile using Immobilized whole-cell in Chitosan-TPP Beads.

\section{3) Immobilized whole-cell in chitosan-TPP}

Fig. 7 shows that the predicted result fit fairly with experimental result of immobilized whole-cell in chitosan-TPP beads. Utilizing two-step method causes this immobilized whole-cell has lower reaction rate and also 
michaelis constant value.
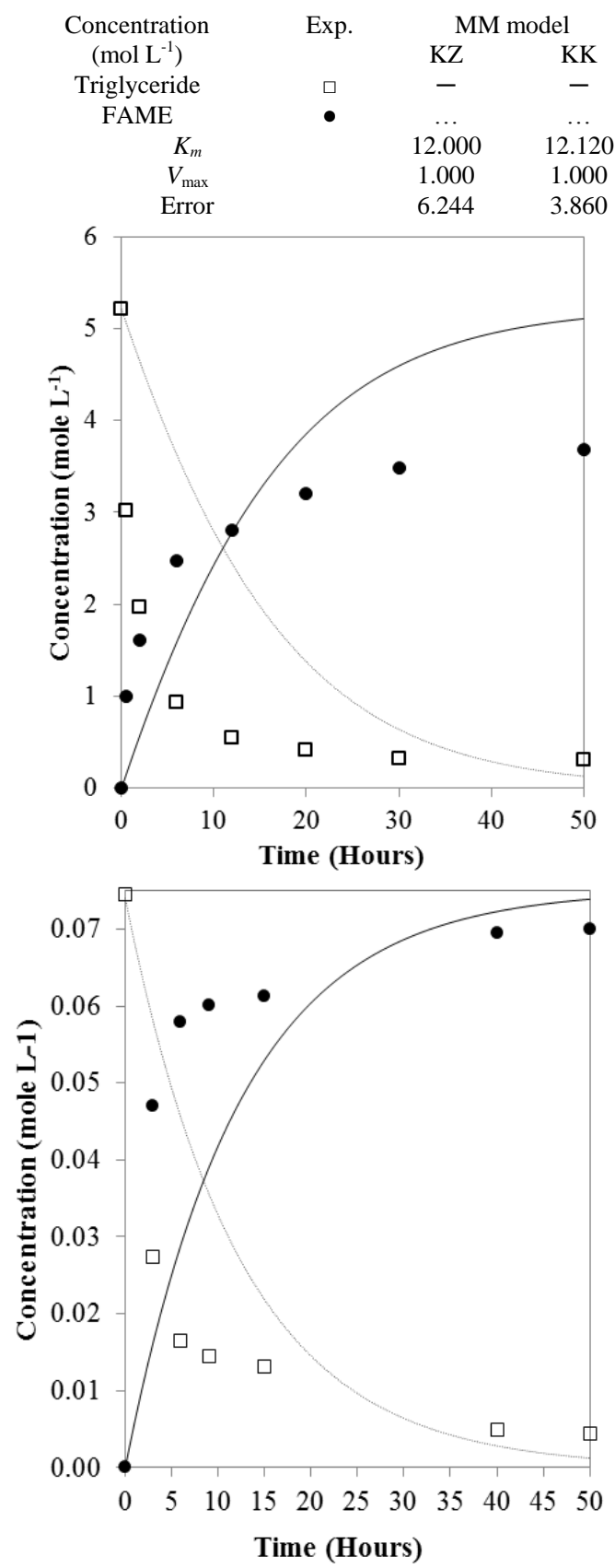

Fig. 8. Triglyceride and FAME profile using immobilized commercial lipase.

\section{4) Immobilized commercially lipase and comparison with whole-cell}

The experimental results using immobilized commercial lipase and the fitted results are shown in Fig. 8. Immobilized lipase on zeolite has same $V_{\max }$ value with immobilized lipase in chitosan-TPP beads. While, the $K_{m}$ value is different. The $V_{\max }$ values of these immobilized commercially lipases are much higher than suspended and immobilized whole-cell. This is accordance with the experimental result which shows remarkable higher FAME yield using immobilized commercially lipase than whole-cell.

\section{CONCLUSION}

We have demonstrated the interesterification of cooking oil and methyl acetate using suspended and immobilized whole-cell of R. oryzae. The novel biodiesel production system using encapsulated whole-cell in chitosan-TPP beads here seems to be a promising alternative to the entrapped whole-cell on BSPs, where the FAME yield was higher.

Michaelis-Menten based kinetic model proposed in this work could predict the substrate and product concentration profile in whole cell-catalyzed biodiesel synthesis along the reaction time since it has a good agreement the experimental results.

\section{ACKNOWLEDGEMENT}

This work was supported by Indonesian Ministry of Research and Technology ("Sinergi Inovasi Nasional" research grant, RT-2013-1501).

\section{REFERENCES}

[1] S. Hama, H. Yamaji, M. Kaieda, M. Oda, A. Kondo, and H. Fukuda, "Effect of fatty acid membrane composition on whole-cell biocatalysts for biodiesel-fuel production," Biochemical Engineering Journal, vol 21 , pp. $155-160,2004$

[2] G. Jin and T. J. Bierma, "Whole-cell biocatalysts for producing biodiesel from waste greases," ISTC Reports, Illinois Sustainable Technology Center, 2010.

[3] L. Fjerbaek, P. Westh, K. V Christensen, and B. Norddahl, "Thermochimica acta novel investigation of enzymatic biodiesel reaction by isothermal calorimetry," Thermochimica Acta, vol. 501, no. 1-2, pp. 84-90, 2010

[4] H. Hermansyah, A. Wijanarko, and R. Arbianti, "Interesterification of triglyceride with methyl acetate using lipase to produce biodiesel," Journal of Bioscience and Bioengineering, vol. 108, 2009.

[5] M. J. Haas, A. J. McAloon, W. C. Yee, and T. A. Foglia, “A process model to estimate biodiesel production costs," Bioresource Technology, vol. 97, pp. 671-678, 2006.

[6] H. Hermansyah, S. Marno, R. Arbianti, T. S. Utami, and A. Wijanarko, "Interesterifikasi minyak kelapa sawit dengan metil asetat untuk sintesis biodiesel menggunakan candida rugosa lipase terimobilisasi," Jurnal Teknik Kimia Indonesia, vol. 8, no. 1, pp. 24-32, 2009.

[7] H. Hermansyah, I. Afridawaty, and M. B. Faiz, "Optimizing lipase immobilization on chitin by entrapment method as biocatalyst for non-alcohol route of biodiesel synthesis," in Proc. 2012 4th International Conference on Chemical, Biological and Environmental Engineering, 2012, p. 16.

[8] H. Hermansyah, M. B. Faiz, I. A. Sipangkar, and R. J. Yosua, "Optimizing lipase immobilization by entrapment method on chitosan as biocatalyst for biodiesel synthesis," in Proc. 19th Regional Symposium on Chemical Engineering, 2012.

[9] H. Hermansyah, R. Arbianti, and D. A. Prameshwari, "Non-alcohol route of biodiesel synthesis from used cooking oil using immobilized biocatalyst in packed bed reactor," Journal of Sustainable Energy, vol. 2, pp. 1-5, 2011

[10] S. N. Hashemizadeh, O. Tavakoli, F. Tabandeh, A. A. Karkhane, and Z. Forghanipour, "Comparative study of immobilized-whole cell and commercial lipase as a biocatalyst for biodiesel production from soybean oil," in Proc. World Renewable Energy Congress, 2011, no. 1, pp. 311-318.

[11] S. Arai, K. Nakashima, T. Tanino, C. Ogino, A. Kondo, and H. Fukuda, "Enzyme and microbial technology production of biodiesel fuel from soybean oil catalyzed by fungus whole-cell biocatalysts in ionic liquids," Enzyme and Microbiokogy Technology, vol. 46, pp. 51-55, 2010.

[12] K. Ban, S. Hama, K. Nishizuka, M. Kaieda, T. Matsumoto, A. Kondo, H. Noda, and H. Fukuda, "Repeated use of whole-cell biocatalysts immobilized within biomass support particles for biodiesel fuel production," Journal of Molecular Catalysis, vol. 17, pp. 157-165, 2002.

[13] K. Ban, M. Kaieda, T. Matsumoto, A. Kondo, and H. Fukuda, "Whole cell biocatalyst for biodiesel fuel production utilizing rhizopus oryzae cells immobilized within biomass support particles," Biochemical Engineering Journal, vol. 8, pp. 39-43, 2001.

[14] S. Hama, S. Tamalampudi, T. Fukumizu, K. Miura, H. Yamaji, A Kondo, and H. Fukuda, "Lipase localization in rhizopus oryzae cells immobilized within biomass support particles for use as whole-cell 
biocatalysts in biodiesel-fuel production," J. Biosci. Bioeng., vol. 101, no. 4, pp. 328-333, 2006.

[15] S. Hama, H. Yamaji, T. Fukumizu, and T. Numata, "Biodiesel-fuel production in a packed-bed reactor using lipase-producing Rhizopus oryzae cells immobilized within biomass support particles," Biochem. Eng. J., vol. 34, pp. 273-278, 2007.

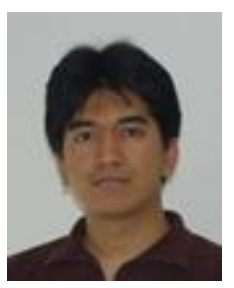

H. Hermansyah was born at Sukabumi on January 18, 1976. Hermansyah is a member of Konsorsium Bioteknologi Indonesia (KBI). He received his bachelor's degree in gas and petrochemical engineering from Universitas Indonesia, Depok, Indonesia in 1998, the M.Eng and $\mathrm{PhD}$ degrees in chemical engineering from Tohoku University, Sendai, Japan in 2003 and 2006, respectively.

$\mathrm{He}$ is the head of Bioprocess Technology Study Program at the Chemical Engineering Department, Universitas Indonesia, Depok 16424, Indonesia. He started his academic career as a lecturer in chemical engineering at Universitas Indonesia. He became a full professor in 2013. On 2010, he published a book with title "Kinetics of biocatalyts (Kinetika Biokatalis)" in UI press. He has published many research articles about biodiesel synthesis through non-alcohol route. He has strong interest in the area of enzyme kinetics modelling, biocatalysis and reaction process engineering.

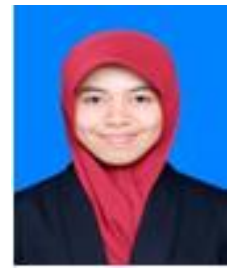

M. B. Faiz was born at Cianjur on May 2, 1992. She completed her bachelor's degree in bioprocess technology in 2012 and master's degree in chemical engineering in 2013 from Universitas Indonesia, Indonesia.

She works as a lecturer at the Department of Chemical Engineering, Universitas Indonesia, Depok 16424, Indonesia. Between November 2012 and February 2013, she did summer research project in Australian Institute of Bioengineering and Nanotechnology (AIBN), Queensland, Australia. She has research interest in the field of biocatalysis.

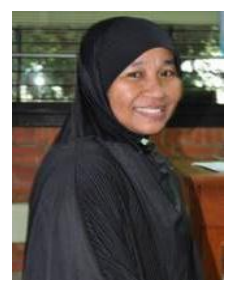

R. Arbianti was born at Bukittinggi on February 2, 1969. Arbianti received the bachelor degree in gas and petrochemical engineering in 1995 and master degree in natural chemical in 2003 from Universitas Indonesia, Indonesia.

She works as a lecturer at the Department of Chemical Engineering, Universitas Indonesia, Depok 16424 , Indonesia. She has major interest in natural chemicals. 